\title{
PRODUKSI SIMBOL DALAM SAMPUL BUKU SASTRA TERBITAN GRAMEDIA
}

\author{
Saeful Anwar \\ Pascasarjana Ilmu Sastra FIB UGM \\ asaefulanwar@gmail.com
}

\begin{abstract}
Abstrak
Perkembangan sampul buku sastra mengalami kemajuan yang pesat seiring teknologi desain dan percetakan. Sampul buku sastra tidak lagi hanya berisi judul, nama pengarang, dan nama penerbit, tetapi telah dipenuhi oleh simbol-simbol teks lainnya seperti anak judul, frasa penjelas judul, frasa penjelas penulis, keterangan jenis buku, kalimat kutipan dari isi buku, komentar penulis lain, dan lain sebagainya. Teks-teks itu kerap diterakan dalam sampul depan buku sehingga bagian tersebut terlihat sesak oleh teks. Gramedia adalah salah satu penerbit yang mempertahankan judul dan nama pengarang di bagian sampul depan tanpa imbuhan teks lainnya yang dapat memenuhi bagian tersebut. Keterangan-keterangan lain mengenai buku atau penulisnya ditempatkan di bagian sampul belakang. Mengapa Gramedia melakukan hal itu diuraikan dalam kajian ini yang mendasarkan cara kerjanya pada teori sosiologi sastra Bourdieu. Dari hasil kajian ditemukan bahwa Gramedia melakukan sejumlah strategi pertukaran modal simbolik antarpenulis yang karyanya diterbitkan perusahaan itu. Pertukaran modal simbolik itu secara tidak langsung digunakan untuk meningkatkan penjualan buku sastra. Gramedia melakukan langkah yang halus dalam menjual buku sastranya sehingga modal simbolik buku dan pengarang yang berafiliasi dengannya tetap terjaga. Pada akhirnya modal simbolik yang banyak ditukarkan itu semakin bertumpuk dan meningkatkan modal ekonomi penerbit tersebut.
\end{abstract}

Kata kunci: Produksi Simbol_Gramedia_Sampul buku sastra—Sosiologi sastra Bourdieu.

\begin{abstract}
As the design and printing technology develops rapidly, the covers' design of literary books on store develops as well. The covers tell not only title, writer's name, and publisher, but also show textual symbols such as subtitle, phrases describing title, phrases describing writer, book category, quotes of the content, other writer's comment, and more. Those additional texts make the cover look full. Gramedia is one of the publishers which keeps putting only title and writer's name on the book covers without adding up more additional texts mentioned above. Instead, the publisher put the additional texts on the back cover. This article aims at explaining why Gramedia keeps the design of book covers that way. This article applies method of Bourdieu's theory on literary sociology. The result shows that Gramedia applies a strategy of symbolic capital exchange among the writers whose works published by Gramedia. The symbolic capital exchange is used indirectly to increase the literary books' sale. Gramedia takes a subtle way of the strategy to keep the symbolic capital of the books and their writers affiliated with the publisher. Gradually the publisher gathers more symbolic capital that consequently increase its economic capital.
\end{abstract}

Keywords: symbol production, Gramedia, literary books' covers, literary sociology, Bordieu.

\section{Pendahuluan}

Secara garis besar, Escarpit (2008: 74) menguraikan bahwa penerbit memiliki kegiatan yang terangkum dalam tiga kata kerja, yakni memilih, membuat, dan membagikan. Bagi Escarpit, ketiganya saling berkaitan, masingmasing bergantung satu sama lain, dan saling memengaruhi, serta membentuk satu siklus yang merupakan keseluruhan kegiatan penerbitan. Meskipun saling berkaitan, tulisan ini hanya akan mengkaji salah satu dari ketiganya, yakni kegiatan membuat, lebih khusus lagi bagaimana sampul dibuat oleh sebuah penerbit.

Sampul menjadi salah satu media menawarkan buku kepada calon pembaca atau pembeli. Dari beberapa kali pengamatan ke sejumlah toko buku, hanya sedikit orang yang menggunakan search engine atau menanyakan kepada pelayan tentang letak buku sastra yang diinginkannya untuk kemudian mencari, menemukan, dan membelinya. Fakta ini menunjukkan dua hal, pertama, ada calon 


\section{Jurnal Poetika Vol. III No. 2, Desember 2015}

pembeli yang langsung mencari buku dengan referensi yang ada di kepalanya dan, dua, ada calon pembeli yang membeli buku hanya karena melihat dan membaca apa yang tertera di sampulnya, tanpa adanya referensi. Sampul menjadi salah satu media yang dapat memunculkan motivasi untuk membaca/ membeli buku bagi publik yang tidak memiliki referensi bacaan.

Hal ini diperkuat dengan adanya fenomena epigonasi terhadap sampul buku-buku sastra yang pernah best seller, sehingga pernah terjadi pada beberapa waktu merebaknya sampul buku sastra yang mirip dengan novel Gajah Mada, Laskar Pelangi, dan Ayat-ayat Cinta, baik dari segi permainan warna, ilustrasi, jenis huruf, maupun kata-kata yang diterakan di atasnya. Di sisi lain sampul buku sastra mengalami perkembangan pesat dari segi elemen yang mengisinya. Sampul kini tidak lagi hanya berisi ilustrasi, judul, nama penulis, dan nama penerbit, tetapi juga ditambahkan beberapa materi seperti endorsement, anak judul, frasa penjelas judul, frasa penjelas penulisnya, kutipan isi buku, dan lain sebagainya, yang ditujukan untuk menarik perhatian pembaca.

Tulisan ini mengkaji bagaimana penerbit Gramedia Pustaka Utama (selanjutnya disebut Gramedia) memproduksi simbol dalam sampul buku sastra mereka. Sebagaimana diketahui, Gramedia menjadi penerbit skala besar dalam dua arti, besar modal ekonominya dan besar modal simboliknya. Bagaimana kedua hal itu dapat berjalan beriringan dapat dilihat salah satunya dari cara Gramedia memproduksi simbol dalam sampul buku sastranya. Sebagai penerbit yang tidak hanya menerbitkan buku sastra, Gramedia telah melakukan cara kerja yang rapi dalam menukar modal ekonomi dan modal simbolik dalam penerbitan bukubukunya. Tentu dibutuhkan kajian lebih lanjut mengenai hal itu dan diharapkan kajian kecil ini mampu memulainya dari sampul buku.

Kajian tentang sampul buku telah menjadi bagian dari teori parateks yang dikembangkan oleh Gerard Genette melalui Paratext: Thresholds of Interpretation (1997). Dalam buku itu Genette menyebutkan bahwa kehadiran teks_-dalam hal ini buku-jarang muncul dalam keadaan tidak berhias, tidak diperkuat, dan tidak dilengkapi oleh beberapa produksi verbal atau lainnya, seperti nama penulis, judul, prakata, ilustrasi (1997: 1). Genette menguraikan bahwa parateks terdiri dari unsur-unsur berikut: nama penulis, judul, subjudul, teks antara, prakata, kata pengantar, epilog, catatan, epigraf, ilustrasi, komentar sampul, sampul, dan beragam sinyal sekunder lainnya, baik yang alografis maupun otografis. Dengan demikian, parateks adalah unsur-unsur sekunder di luar teks utama.

Tulisan ini tidak mengkaji seluruh unsur parateks yang diperikan Genette tersebut dan membatasi fokus hanya pada sampul. Selain itu, tulisan ini juga tidak membahas relevansi antara sampul dengan isi buku dengan menjelaskan makna dan kedekatan dengan isinya. Seperti dikatakan Genette (1997: 3) teks tanpa parateks tidaklah eksis dan tidak akan pernah eksis, sebaliknya, parateks tanpa teks dapat eksis. Maka tulisan ini akan mengkaji kehadiran sampul buku sastra di hadapan publik dengan mengaitkannya dalam sosiologi sastra Pierre Bourdieu, khususnya dengan dunia penerbitan. Sementara unsur sampul yang dikaji pun dibatasi hanya yang berupa teks di luar nomor ISBN, barcode, dan nama serta alamat penerbit.

\section{Penerbitan dalam Teori Bourdieu}

Berdasarkan kajiannya terhadap rumah penerbitan di Prancis, Bourdieu membagi dua macam penerbit, yakni penerbit jangka panjang dan jangka pendek. Pembagian ini mengacu pada perbedaan komitmen mereka antara investasi jangka panjang yang berisiko-yang diilustrasikan Bourdieu sebagai Godot-dan investasi jangka pendek yang aman, dan dengan cara yang sama, berdasarkan perbedaan karakter para penulis mereka, apakah penulis jangka panjang atau penulis jangka pendek (Bourdieu, 


\section{Jurnal Poetika Vol. III No. 2, Desember 2015}

2010: 113). Penerbit jangka panjang menerbitkan buku sastra yang mungkin tidak segera laku pada masa sekarang, tetapi diharapkan tetap dapat dijual pada masa mendatang. Sementara itu, penerbit jangka pendek memproduksi buku sastra dengan maksud meraih keuntungan ekonomi sebanyak mungkin dalam waktu sesingkat mungkin.

Sejatinya keduanya memiliki risiko yang sama, yakni buku-buku yang diterbitkannya itu tak laku kecuali diobral dengan harga yang lebih rendah daripada ongkos produksinya. Namun, penerbit jangka panjang memiliki waktu yang lebih lama untuk-atau bahkan berusaha agar sama sekali tidak-mengobral produknya, sedangkan penerbit jangka pendek memiliki tenggat waktu yang pendek untuk mengobral produknya. Dengan posisi yang demikian, keduanya memiliki cara-cara tersendiri dalam mengemas produknya untuk ditawarkan kepada pembaca/pembeli.

Apabila mengacu pada konsep arena dan modal yang digagas Bourdieu, maka penerbit jangka panjang adalah mereka yang mengerti dan paham aturan main dalam arena sastra, sehingga strategi dalam mengemas produknya pun tidak dengan cara-cara biasa, melainkan dengan sejumlah simbol sebab arena sastra adalah tempat pertaruhan modal simbolik para "pemainnya". Hukum dalam arena ini adalah bahwa makin tak kelihatan investasi, makin produktif dia secara simbolik sehingga promosi yang dilakukan harus diperhalus, berbeda dari publikasi terang-terangan yang berlaku di dunia bisnis biasa (Bourdieu, 2010: 78).

Di sisi yang lain, penerbit jangka pendek adalah mereka yang sedikit mengerti arena sastra, sehingga mereka mengabaikan perihal modal simbolik karena pandangannya lebih berat kepada modal ekonomi sehingga apa yang disebut "sastra" hanya menjadi salah satu jenis dagangan dari sekian macam produk lainnya seperti, "komputer", "pertanian”, "olahraga", dan lain sebagainya. Akibatnya, buku sastra akan dipromosikan dengan cara yang sama dengan produk dagangan lainnya. Bagi penerbit jangka pendek, penerbitan buku sastra tak jarang hanya selingan dari buku-buku jenis lainnya, sebagai pelengkap kategori terbitan mengingat sulitnya penjualan buku sastra.

Bourdieu lebih banyak membahas hubungan penerbit dan penulis dalam arena sastra dengan menyinggung perihal penjualan buku-buku sastra. Ketika menjelaskan strategi-strategi yang digunakan penerbit dalam mempromosikan produknya, ia lebih banyak menyinggung relasi antaragen dalam mengkonsekrasi karya dan penulisnya daripada bagaimana buku diciptakan dan dikemas dengan simbol-simbol tertentu. Meskipun demikian, konsepnya mengenai modal, arena, dan strategi, serta pembagian jenis penerbit ini mendasari cara kerja kajian ini.

\section{Sampul: Ruang Pertukaran Modal Simbolik}

Gramedia sangat selektif memilih karya mana yang akan diterbitkan dengan pertimbangan yang seimbang antara menjaga modal simbolik yang telah dimilikinya dan modal ekonomi yang akan diraihnya. Hampir tidak mungkin suatu karya diterbitkan Gramedia bila karya atau pengarangnya belum memiliki prestasi. Hal itu dimungkinkan terjadi ketika Gramedia memiliki proyek penulisan yang mencoba melahirkan para penulis dari ajang yang dibuatnya, seperti Gramedia Writing Project. Tentu, ini merupakan usaha untuk melepaskan diri dari citra Gramedia yang kerap "mengambil" karya atau penulis tertentu yang telah sukses sebelumnya (akan terlihat dalam salah satu kasus pada kajian ini).

Apabila karya atau pengarangnya telah memiliki prestasi atau modal simbolik yang cukup untuk diperjuangkan dalam arena sastra, Gramedia berusaha agar modal itu tidak terkurangi atau malah hilang dengan sejumlah simbol yang justru dapat memiskinkannya. Maka, dalam muka buku atau sampul depan, buku-buku sastra terbitan Gramedia hampir selalu hanya berisi judul dan nama penulisnya, 
seperti misalnya pada karya-karya milik Sindhunata, Seno Gumira Ajidarma, Joko Pinurbo, Triyanto Tiwikromo, Raudal Tanjung Banua, dan Eka Kurniawan (lihat Gambar 1). Kalaupun ada tambahan, itu berupa teks yang menjelaskan jenis buku tersebut, apakah novel, cerpen, atau puisi.

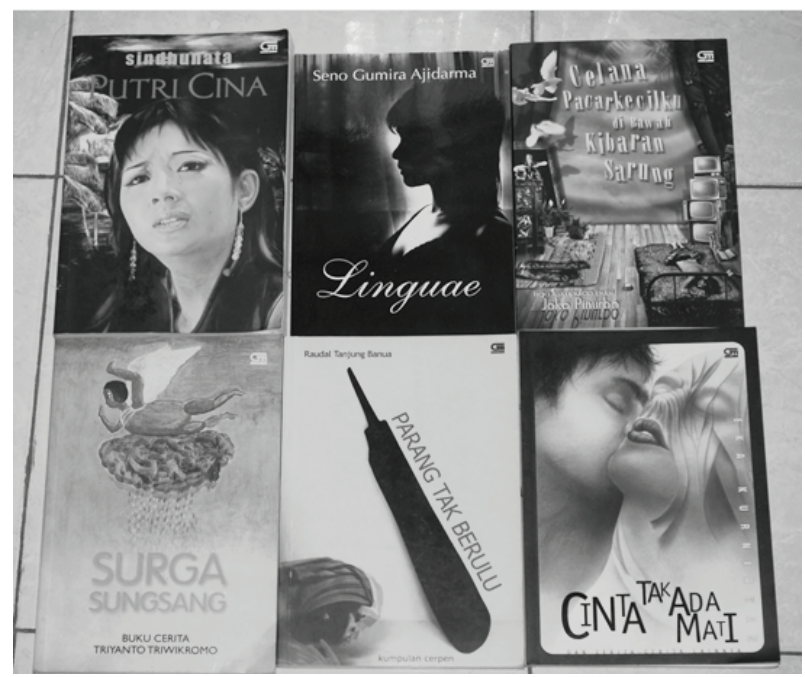

Gambar 1. Contoh muka buku atau sampul depan buku sastra terbitan Gramedia yang menonjolkan judul dan nama pengarang.

Hal ini berlaku pula bagi buku sastra terjemahan (lihat gambar 2). Khusus untuk beberapa sastra terjemahan, diikutkan pula judul dalam bahasa Inggrisnya, misalnya pada The Fifth Mountain (Gunung Kelima) karya Paulo Coelho, Chicken With Plums (Ayam dengan Plums) karya Marjane Satrapi, dan Grostesque (Gaib) karya Natsuo Kirino. Bagi karya yang telah lebih dulu tenar dalam versi bahasa Inggris-nya, judul bahasa Inggris dibuat lebih besar daripada judul terjemahannya. Apabila karya tersebut merupakan sebuah karya best-seller, akan disertakan keterangan tersebut dalam muka buku, seperti Imperium karya Robert Harris.

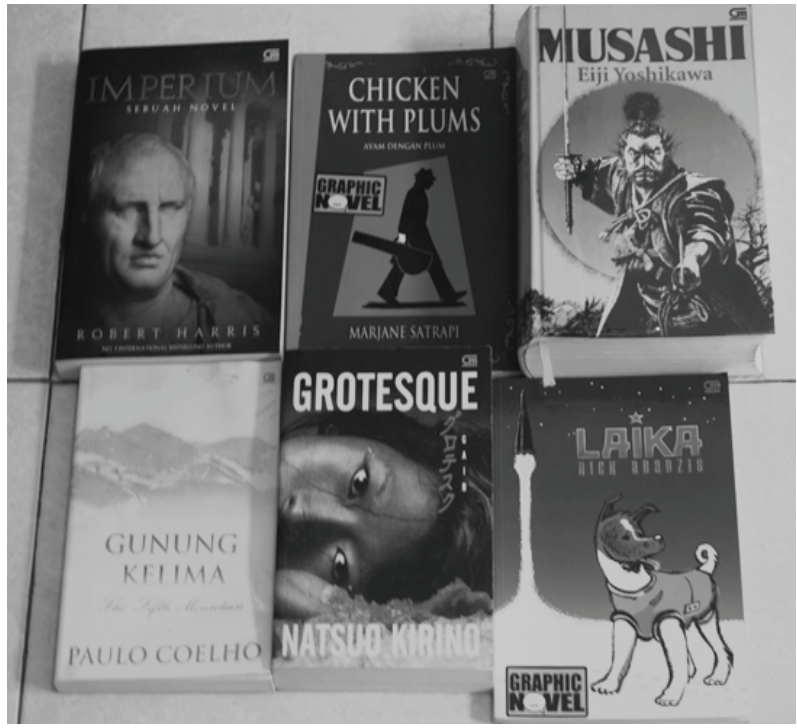

Gambar 2. Contoh muka buku atau sampul depan buku sastra terjemahan Gramedia yang menonjolkan judul bahasa Inggris daripada judul terjemahannya.

Gramedia akan menambahkan elemen lain dalam muka buku apabila buku tersebut dicetak ulang karena prestasi yang telah diraihnya-prestasi yang diraih setelah diterbitkan Gramedia. Kasus seperti ini dapat dilihat misalnya, dalam sejumlah peralihan sampul Cantik Itu Luka karya Eka Kurniawan setelah diterbitkan Gramedia yang sebelumnya diterbitkan oleh Akademi Kebudayaan Yogyakarta dan Penerbit Jendela (lihat gambar).

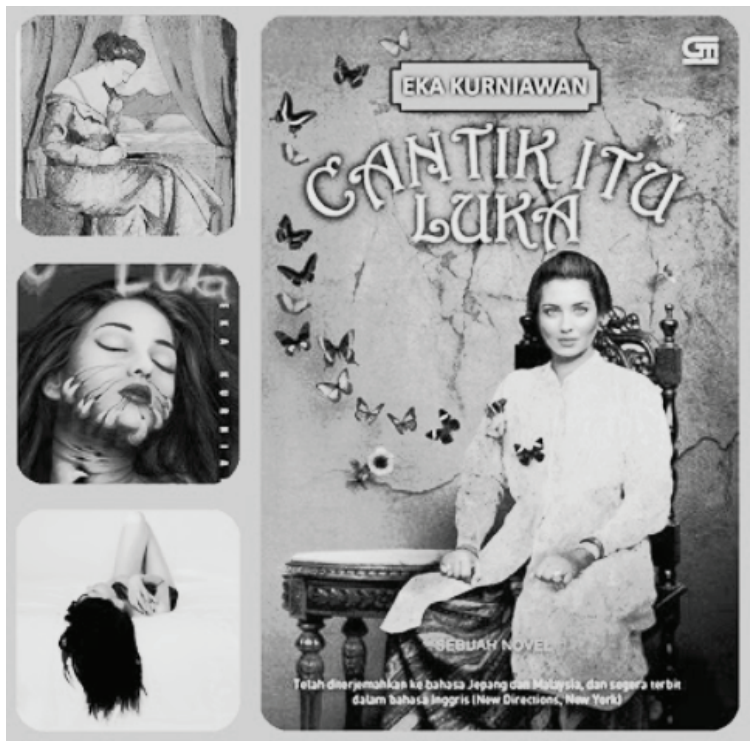


Gambar 3. Peralihan muka buku Cantik Itu Luka dari awal yang hanya berisi judul dan nama pengarang (pada edisi pertama dan kedua) lalu pada edisi ketiga ditambahkan keterangan "sebuah novel" dan "telah diterjemahkan dalam bahasa Jepang dan Malaysia" (keduanya tidak terlihat digambar) dan pada edisi keempat keterangan itu ditambahkan "...dan segera terbit dalam bahasa Inggris (New Directions, New York)". Sumber gambar dari www.ekakurniawan.com

\section{Genette (1997: 75) menganggap} bahwa judul secara langsung lebih banyak tertuju kepada orang daripada teks (yang ada di dalamnya). Semakin luas jangkauan sebuah judul, semakin besar kemungkinan buku itu dibeli/dibaca. Judul-judul buku sastra Gramedia telah dibuat lebih luas dari teks yang ada di dalamnya, sehingga tidak perlu ditambahkan kata-kata yang lain untuk menjelaskannya. Semakin banyak sesuatu dijelaskan, justru akan semakin sempit jangkauannya. Penerbitpenerbit di luar Gramedia justru banyak menyertakan elemen teks lain yang ingin menerangkan judul atau isi buku dengan anak judul, frasa penjelas judul, atau kalimat yang dianggap mewakili isi buku, sehingga muka buku terlihat sesak dan pengertian terhadap isi buku semakin disempitkan, bahkan cenderung diarahkan (lihat gambar 4).

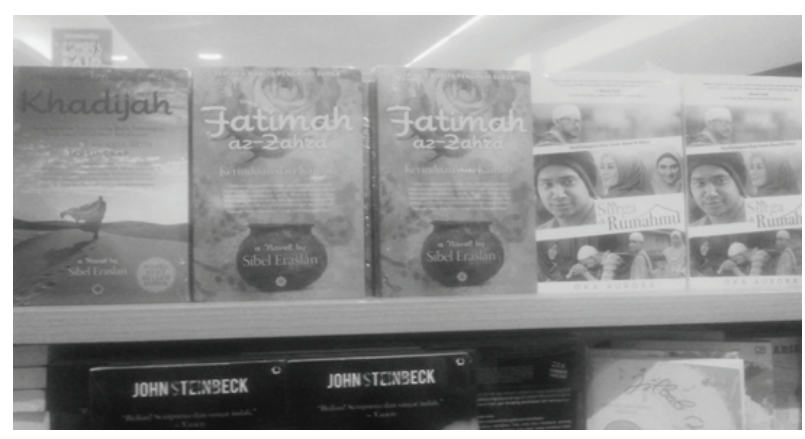

Gambar 4. Contoh buku sastra terbitan lain di luar Gramedia yang menyertakan sejumlah simbol yang memenuhi muka buku sehingga nama pengarang dan judul-yang kebetulan adalah tokoh panutan dalam suatu agamaterlihat kurang dapat "menjual".
Seperti jelas terlihat, tambahan-tambahan keterangan seperti yang diterakan pada buku Cantik Itu Luka bukanlah untuk menjelaskan judul atau isi buku, melainkan menerangkan kepada calon pembaca/pembeli prestasi yang telah diraih buku tersebut dengan simbolsimbol nama bahasa, yakni Malaysia, Jepang, dan Inggris, yang menunjukkan betapa buku itu pantas untuk dibaca atau dimiliki. Selain itu, penyebutan nama penerbit New Directions dan kota New York yang akan menerbitkan buku tersebut dalam bahasa Inggris juga menunjukkan betapa karya itu telah menyamai prestasi beberapa karya sastra dunia yang banyak diterbitkan oleh penerbit itu dan disebarkan dari kota itu. Dengan adanya keterangan-keterangan tersebut, Gramedia mencoba meningkatkan penjualan buku tersebut tanpa mengurangi modal simbolik judul dan pengarangnya yang telah ternama, bahkan justru menambahkan modal simboliknya untuk ditukarkan dengan materi yang dimiliki calon pembaca/pembeli.

Sementara itu, secara garis besar, pada sampul belakang buku-buku sastra Gramedia diterakan kutipan isi buku, deskripsi isi buku, biodata pengarang, komentar media massa, atau komentar penulis lain atas buku tersebut atau tentang pengarangnya. Sebagian besar sampul belakang buku sastra terjemahan Gramedia berisi kutipan atau deskripsi isi buku, sementara buku sastra Indonesia didominasi oleh komentar penulis lain meskipun beberapa di antaranya hanya menyertakan kutipan atau deskripsi isi. Apa yang menarik dari sampul belakang ini adalah nama-nama penulis yang bukunya pernah diterbitkan Gramedia-atau jaringannya-akan memberikan pernyataan kepada penulis lain, atau penulis yang lebih baru sebagai bentuk legitimasi bahwa buku itu baik atau layak dimiliki.

Apakah cara kerja demikian juga berlaku bagi buku-buku baru yang ditulis oleh pengarang yang baru atau masih asing dalam arena sastra Indonesia? 


\section{Sejumlah Nama dalam Buku Baru}

Muka buku yang berisi judul dan nama pengarang tidak hanya diterapkan pada buku karya para penulis yang sebelumnya telah dikenal publik sastra melalui media massa atau buku-buku sebelumnya, seperti Eka Kurniawan, Agus Noor, Triyanto Tiwikromo, Seno Gumira Ajidarma, dan lain sebagainya, melainkan juga pada karya penulis yang mungkin masih asing bagi sebagian publik sastra Indonesia seperti Sobron Aidit (lihat buku Prajurit yang Bodoh, 2006), yang mungkin hanya diketahui publik sastra di Indonesia secara terbatas seperti Maggie Tiojakin (Balada Ching-Ching dan Balada Lainnya, 2010), atau nama-nama baru seperti Laksmi Pamuntjak ( $A m b a$, saat cetakan pertama 2012) dan Mario F. Lawi (Lelaki Bukan Malaikat, 2015). Nama-nama itu sejatinya tidak kosong prestasi atau nirkarya, tetapi Gramedia tidak menuliskan jejak prestasi dan karya itu di muka buku (lihat gambar 5). Gramedia menaruhnya di sampul belakang beserta dengan komentar orang-orang yang memiliki kapasitas atau pengalaman di bidang penulisan karya sastra, para ahli, atau komentar media terhadap karya mereka.

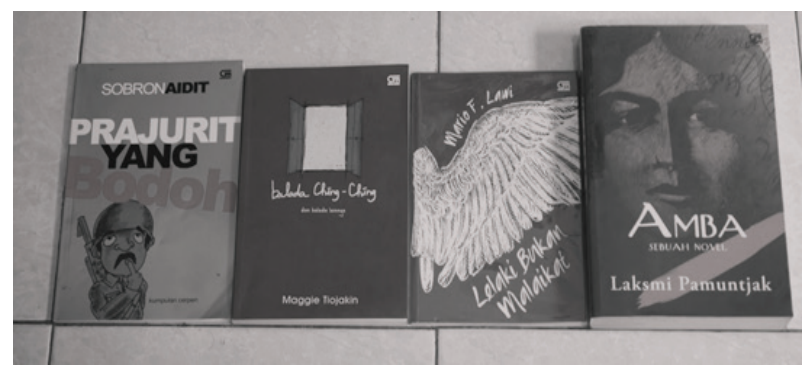

Gambar 5. Contoh buku baru dengan nama yang relatif baru bagi arena sastra Indonesia saat kemunculan buku-buku tersebut.

Untuk buku Sobron Aidit, pada sampul belakangnya dituliskan kesan dari Fira Basuki (penulis best seller untuk sejumlah novel) dan Rieke Diah Pitaloka (penulis sekaligus artis). Pertanyaannya, mengapa komentar dari kedua nama itu yang diterakan di halaman sampul belakang? Ada nama-nama yang dapat memberikan modal simbolik lebih besar atas karya itu dari sejarawan, kritikus sastra, atau sastrawan seangkatan dengan Sobron Aidit. Namun, popularitas kedua nama itu lebih diharapkan sebagai pendongkrak — terutama dalam penjualan-karya Sobron Aidit tersebut, yang setelah lima tahun akhirnya buku itu diobral. Tidak menutup kemungkinan sasaran minimal penjualan buku tersebut adalah pengagum Fira Basuki dan Rieke Diah Pitaloka. Tentu, ini menjadi strategi penerbit sebagai imbal balik atas usahanya menerbitkan karya seorang pengarang yang di mata khalayak umum masih sering dikaitkan dengan Aidit yang lain, sesuatu yang dapat tidak menguntungkan secara ekonomi.

Dalam kasus Maggie Tiojakin justru terjadi kompleksitas pencitraan. Di halaman sampul belakangnya terdapat deskripsi singkat isi buku, komentar dari penulis lain atau komentar yang dikutip dari media massa, dan alamat website penulisnya. Dengan komponen itu, sampul belakang terlihat sesak dan membingungkan sebab dua dari tiga komentar yang ditulis tidak ditujukan untuk karya itu, melainkan untuk karya Maggie sebelumnya yang berjudul Homecoming. Selain itu, pemberi komentar juga terasa asing bagi pembaca sastra Indonesia, seperti Duncan Graham (yang hanya disusulkan nama Jakarta Post setelah nama itu sehingga pembaca berpikir orang ini adalah redaktur harian tersebut) dan Larry Starkey yang dijelaskan sebagai penulis Wilkes Booth Come to Washington. Komentar terakhir berasal dari sebuah jurnal sastra online yang berbasis di Michigan bernama Eastown Fiction, yang tidak diberi keterangan apakah komentarnya itu didasarkan atas buku itu atau dari buku sebelumnya.

Nama-nama yang asing bagi publik sastra Indonesia di sampul buku ini kemungkinan dibuat untuk mencitrakan bahwa karya Maggie telah dikenal di dunia internasional sehingga publik nasional layak pula untuk membacanya. Adapun penulisan alamat 


\section{Jurnal Poetika Vol. III No. 2, Desember 2015}

website penulis menunjukkan sampul buku ini gagal menggambarkan siapa Maggie. Seabrek keterangan dalam sampul belakang ini justru memiskinkan kekuatan Maggie sebagai penulis. Ia seolah bukan siapa-siapa, sehingga perlu diberikan berbagai macam keterangan. Dengan kata lain, secara simbolik, Maggie masih belum memiliki apa-apa dalam arena sastra Indonesia, berbeda dengan penulis Gramedia lainnya yang cukup diberi komentar oleh penulis lainnya maka sudah sah bahwa ia adalah penulis yang bermutu sehingga karyanya layak dibaca atau dikoleksi.

SementaraitubukuLelakiBukanMalaikat karya Mario F. Lawi hanya menampilkan judul dan nama pengarang di sampul depan. Di bagian sampul belakangnya terdapat sebuah kalimat Sapardi Djoko Damono: "Mario Lawi dengan terampil telah memindabkan inti amanat Kitab Suci ke puisi dan menawarkannya kepada pembaca sebagai penghayatan dan pengalaman baru yang tidak lagi perlu dibatasi oleb keyakinan apa pun". Nama Sapardi dan kata "kitab suci" — catat, bukan alkitab_dalam komentarnya telah menunjukkan mangsa pasar yang hendak dituju. Ini adalah cara promosi yang halus sehingga tidak tampak niat untuk menjual karya tersebut.

Di sampul belakang ini juga terdapat dua keterangan yang diimpit gambar padi, yakni (1) Pemenang NTT Academia Award Kategori Sastra 2014 dan (2) Penyair Buku Puisi Terbaik Majalah Tempo 2014. Tentu penyertaan keterangan ini memiliki dua tujuan, yakni menunjukkan modal simbolik penulis buku ini untuk ditukarkan dengan modal ekonomi calon pembaca/pembeli. Dua keterangan ini sejatinya lebih menjelaskan prestasi penulisnya, bukan buku yang sedang disajikan. Sebagaimana diketahui, Mario F. Lawi meraih kedua prestasi yang dicantumkan tersebut melalui karya perdananya, yakni Ekaristi (PlotPoin, 2014). Namun, penerbit mengaburkan antara prestasi penulis melalui karya terdahulunya dan prestasi karya yang baru diterbitkannya, seperti juga yang berlaku pada karya Maggie Tiojakin sebagaimana telah diuraikan sebelumnya.

Ketiga contoh karya di atas merupakan karya yang pertama kali diterbitkan Gramedia dan belum dicetak ulang sehingga tidak dapat dikaji lebih lanjut. Lalu bagaimana dengan buku yang mengalami cetak ulang? Amba dapat menjadi contoh yang layak untuk dikaji. Pada awal kemunculannya, sampul depan Amba hanya berisi judul dan nama pengarangnya dengan satu frasa penerang bahwa buku itu sebuah novel. Di bagian belakang terdapat deskripsi singkat isi dan empat komentar dari Sitok Srengenge (penyair, novelis, esais), Dewi Lestari (penulis buku bestseller), Ariel Haryanto (Associate Professor of Indonesia Studies dan Head of Southeast Asia Centre, The School of Culture, History and Language, Australian National University), dan Amarzan Loebis (Penyair, Senior Editor Tempo, Eks-Tahanan Politik Tefaat Buru). Nama pertama dicitrakan mewakili sastrawan, nama kedua dicitrakan mewakilipenulis best-seller, nama ketiga dicitrakan mewakili ilmuwan, dan nama keempat dicitrakan mewakili saksi sejarah. Keempatnya seragam memberi puja-puji dan kesan bahwa novel ini layak dibaca/dibeli. Di satu sisi, komentar mereka menguatkan kutipan yang dicantumkan di atasnya karena nama, judul, dan keterangan genre di muka buku belum menjelaskan buku ini bercerita tentang apa. Di sisi lain, komentar ini menunjukkan kelemahan dari sisi pemasaran bila sampul buku ini hanya berisi kutipan (yang sekilas menyebut Buru dan G30S sebagai latar dan salah satu peristiwa), nama pengarang (yang saat itu belum banyak diketahui publik sastra siapa dia dan apa karya sebelumnya), judul buku (yang justru mengingatkan publik pada tokoh wayang), dan genre (yang sekadar menunjukkan bahwa ini novel).

Pada akhirnya, elemen-elemen dalam sampul buku itu turut membawa Amba mengalami dua kali cetak ulang (pada November 2012_dua bulan setelah cetakan pertama, September 2012-dan Februari 2013) kemudian dicetak ulang kembali dengan 
edisi baru (pada Oktober 2013) dengan status baru sebagai karya best-seller. Pada edisi baru ini bagian sampul depannya, selain ada nama pengarang, judul, dan genre, telah ditambahi keterangan "A National Bestseller", potongan komentar Amarzan Loebis yang sebelumnya ada di sampul belakang edisi sebelumnya, dan keterangan "Edisi Baru" (lihat gambar 6).

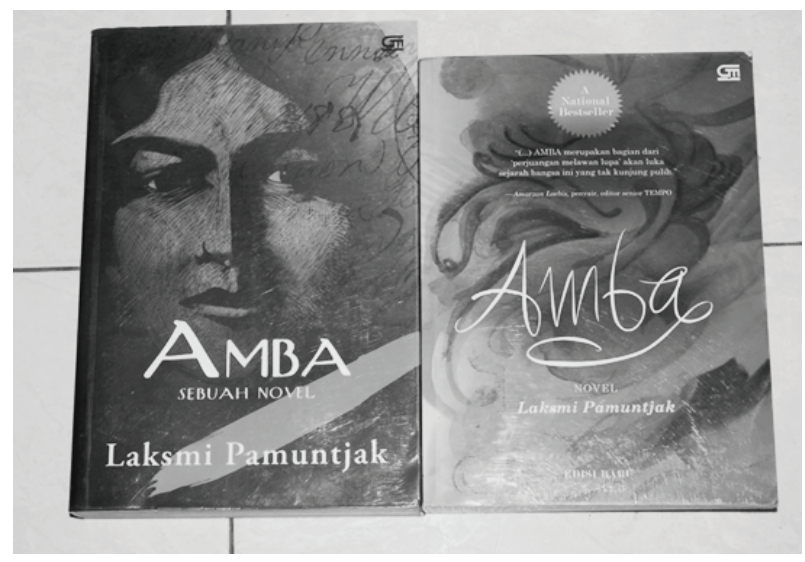

Gambar 6. Perbedaan antara muka buku Amba saat pertama kali terbit dengan saat diterbitkan dalam edisi baru.

Muka buku yang baru ini menunjukkan bahwa Amba telah meraih prestasi dengan dibaca banyak orang. Apa yang menarik adalah di bawah logo best-seller langsung diteruskan potongan kalimat Amarzan Loebis: “...Amba merupakan bagian dari 'perjuangan melawan lupa' akan luka sejarah bangsa ini yang tak kunjung pulih." Kalimat ini seolah-olah menegasikan kesan best-seller yang selama ini melekat pada karya yang mudah dicerna dan populer. Bahwa ini karya best-seller, tetapi memiliki nilai yang berbeda atau sebab yang berbeda dari karya best-seller yang lain. Ketika karya ini dianggap sebagai bagian 'perjuangan melawan lupa', maka pembaca dapat menjadi pejuang untuk turut "menyembuhkan" luka sejarah yang tak kunjung pulih. Inilah tawaran yang disajikan muka buku bahwa pembaca dapat turut berjuang dengan membeli atau membaca buku ini.
Di bagian sampul belakang tidak hanya berisi deskripsi singkat isi novel dan komentar, tetapi telah ditambahkan nama dan biodata pengarang berikut potretnya. Komentar yang dipertahankan adalah milik Ariel Heryanto sementara komentar yang baru berasal dari Professor Saskia Weirenga (The Jakarta Globe) dan Aamer Husain (novelis). Melalui sampul belakang ini, Gramedia menunjukkan siapa pengarang novel ini yang pada edisi awal keterangan itu masih "disembunyikan" di bagian dalam sampul. Sampul belakang ini juga menunjukkan daya jangkau novel ini yang telah diterjemahkan ke dalam bahasa Inggris sekaligus menunjukkan bahwa karya lain pengarang novel ini telah diapresiasi dengan baik di luar negeri.

\section{Jejaring Kuasa Simbolik}

Pertimbangan komersil terlibat dalam setiap keputusan untuk penerbitan, dan memperkirakan dari mula bahwa penerbit memiliki kemampuan meramalkan, dengan ketelitian tertentu, kemungkinan buku untuk dibaca (Barker dan Escarpit, 1976: 54-55). Persoalan menjadi rumit ketika pertimbangan ini digunakan dalam penjualan buku sastra. Publik sastra berbeda dengan publik pada umumnya, terutama dalam hal ketertarikan. Apa yang mungkin dibaca oleh publik umum, belum tentu dibaca oleh publik sastra. Maka, sebagaimana pernah disinggung sebelumnya, Bourdieu mengatakan bahwa perlu cara yang berbeda dalam mempromosikan buku sastra, yakni cara yang halus, penuh eufemisme, dan yang tidak kentara motif penjualannya. Semakin terkenal sebuah buku sastra secara komersil, semakin lemah modal simbolik yang dimilikinya.

Dari uraian pada bagian sebelumnya dapat dilihat bahwa Gramedia tidak mencitrakan buku-buku sastranya sebagai buku yang laku secara komersil, misalnya dengan menyebutkan telah dicetak berapa kali dan menyertakan angka jumlah eksemplar cetakannya. Kalaupun 


\section{Jurnal Poetika Vol. III No. 2, Desember 2015}

ada tulisan best-seller, keterangan itu langsung ditambahi dengan keterangan lain yang berupa komentar para ahli atau penulis lainnya sehingga kesan best-seller itu menjadi lain dari status buku komersil.

Bourdieu (1990: 141) mengatakan bahwa arena sastra melibatkan kekuasaanseperti kekuasaan untuk mempublikasikan atau menolak publikasi_dan modal seorang pengarang yang telah terkenal dapat dialihkan sebagian kepada pengarang muda dan belum terkenal dengan memberinya review atau kata pengantar positif. Gramedia memiliki kekuasaan atas terbit atau tidaknya suatu karya dalam nama perusahaannya yang digunakan dengan baik ketika menyeleksi karya yang akan diterbitkannya. Selain modal simbolik yang dimilikinya berkat pengarang-pengarang yang ada dalam jaringannya, Gramedia juga menawarkan keuntungan lain, yakni distribusi buku yang lebih baik karena jaringan toko buku yang dimilikinya, sehingga banyak penulis yang berminat karyanya diterbitkan melalui penerbit ini. Di sisi yang lain, Gramedia memanfaatkan penulis-penulis yang dimilikinya untuk berbagi modal simbolik. Di dalam sampul, pertukaran modal simbolik itu terjadi dalam rupa komentar yang berisi pujian, seperti terlihat dari komentar yang diberikan Fira Basuki dan Rieke Dyah Pitaloka terhadap buku Sobron Aidit. Keduanya merupakan penulis yang karya-karyanya pernah diterbitkan oleh Gramedia.

Strategi yang digunakan oleh Gramedia dalam menjual buku sastranya dapat diacu kepada pembagian strategi yang menurut Bourdieu (1984: 125-131) terbagi ke dalam dua macam, yakni (1) strategi reproduksi yang merupakan sekumpulan praktik yang dirancang oleh agen untuk mempertahankan atau meningkatkan modal ke arah masa depan, dan (2) strategi rekonversi yang merupakan sejumlah pergerakan agen dalam ruang sosial yang terstruktur dalam dua dimensi, yakni keseluruhan jumlah modal yang terstruktur dan pembentukan jenis modal yang dominan dan terdominasi. Dari kajian terhadap sampul buku sastra yang diterbitkannya, strategi ini terlihat diterapkan oleh Gramedia dengan cara memperbesar modal simbolik sebuah buku melalui komentar yang berupa pujian penulis lain dalam jaringannya untuk mempertahankan dan meningkatkan modalnya pada masa mendatang. Apabila buku tersebut berhasil meraih modal simbolik yang besar, pada kemudian hari penulisnya akan "dituntut" untuk menulis komentar yang kembali berupa pujian kepada penulis lain yang lebih baru. Pemertahanan dan peningkatan modal simbolik ini, yang terjadi tidak secara simultan, kemudian hari dikonversi menjadi modal ekonomi, baik bagi penerbit maupun penulis yang kelak sukses dalam arena sastra.

Kesuksesan Gramedia menumpuk modal simbolik bagi buku-buku sastra terbitannya tidak lepas dari jaringan yang dimilikinya. Sebagaimana diketahui, Gramedia berada dalam satu grup bersama Kompas. Melalui jaringan media massa yang dimilikinya ini, Gramedia berhasil mengedarkan nama pengarang buku sastra terbitannya secara tidak menentu dalam isu, iklan, percakapan, katalog, resensi, artikel, berita, dan lain sebagainya yang memungkinkan nama pengarang, dalam bahasa Ganette (1997: 38) beredar secara erratic, bukan sekadar circumscribed yang hanya hadir dalam punggung dan sampul buku. Selain itu, Toko Buku Gramedia juga menjadi pendukung utama bagi keajegan modal ekonomi yang dimilikinya, sehingga penerbit Gramedia dapat berkonsentrasi dalam menumpuk modal simbolik bagi buku-buku sastra yang diterbitkannya, termasuk dalam memproduksi simbol dalam sampul buku sastra.

\section{Kesimpulan}

Gramedia memproduksi simbol berupa teks dalam sampul buku-buku sastra yang diterbitkannya melalui beberapa elemen, yakni judul, nama pengarang, genre buku, komentar penulis lain-yang berada dalam jejaringnya-, 
komentar media, kutipan isi, deskripsi isi, biodata penulisnya, dan keterangan prestasi buku atau penulisnya. Secara garis besar, tiga elemen pertama ada di muka buku, sedangkan selebihnya ada di sampul belakang. Tiga elemen pertama memungkinkan pembaca membalik buku sehingga membaca sampul belakang dengan materi-materi yang mampu memunculkan keinginan apakah buku itu layak dibeli atau tidak. Keinginan ini akan dipertimbangkan dengan harga buku tersebut. Harga buku yang ditempelkan di bagian sampul belakang membuat pembaca menimbang apakah harga tersebut sebanding atau tidak dengan modal simbolik yang dimilikinya yang dimunculkan melalui: kutipan isi, deskripsi isi, keterangan prestasi buku atau penulisnya, biodata penulis, dan pujian penulis lain pada buku tersebut.

Sebagai sebuah penerbit, kini Gramedia tidak lagi semata sebuah perusahaan, tetapi telah menjadi simbol dalam arena sastra. Hal ini tidak lepas dari buku-buku sastra yang diterbitkannya dengan nama pengarang yang telah tenar dan dianggap kharismatik. Gramedia mampu menyerap modal simbolik para pengarang yang karyanya pernah diterbitkan olehnya dan dikonversikan menjadi modal ekonomi bagi keberlangsungan perusahaannya.

\section{Daftar Pustaka}

Barker, Ronald dan Robert Escarpit. 1976. Haus Buku. (Terjemahan Sunindyo) Jakarta: Pustaka Jaya

Bourdieu, Pierre. 1984. Distinction a Social Critique of the Judgement of Taste. (Translated by Richard Nice). Cambridge, Massachusetts: Harvard University Press

Bourdieu, Pierre. 1990. In Other Words: Essays Towards a Reflexive Sociology. (Translated by Mattews Adamson) Stanford, California: Stanford University Press.

Bourdieu, Pierre. 2010. Arena Produksi Kultural, Sebuah Kajian Sosilogi Budaya. (Terjemahan
Yudi Santosa). Yogyakarta: Kreasi Wacana

Escarpit, Robert. 2008. Sosiologi Sastra. (Terjemahan Ida Sundari Husen). Jakarta: Yayasan Obor Indonesia

Genette, Gerard. 1997. Paratexts: Thresholds of Interpretation. (Translated by Jane E. Lewin). Cambridge: Cambridge University Press (Transferred to digital printing 2001). 